\title{
An estimate of women's contribution to agricultural and regional communities in Australia
}

Prepared for the International Journal of Green Economics

by

\section{Dr Therese Jefferson}

(Senior Research Fellow)

Women in Social \& Economic Research (WiSER)

Graduate School of Business, Curtin University of Technology

PO Box U1987, Perth, Western Australia, 6845

Email: Therese.Jefferson@cbs.curtin.edu.au

and

\section{Anusha Mahendran}

(Research Associate)

Centre for Labour Market Research

Curtin Business School, Curtin University of Technology

PO Box U1987, Perth, Western Australia, 6845

Email: Anusha.Mahendran@cbs.curtin.edu.au 


\section{Biographical Notes - Dr Therese Jefferson}

Therese Jefferson is a Senior Research Fellow with the Graduate School of Business and the Women in Social \& Economic Research (WiSER) unit at Curtin University. She has been involved with a wide range of applied economic and social research. Therese's research has been published in various journals, including the Cambridge Journal of Economics, Feminist Economics, Journal of Economic Methodology and the Encyclopedia of Political Economy.

\section{Biographical Notes - Anusha Mahendran}

After finishing her undergraduate qualifications at the University of Western Australia (UWA), Anusha was awarded a scholarship to do her Masters degree at Curtin University. She has also been involved in completing research for the Centre for Labour Market Research (CLMR) in a diverse range of fields including labour, gender \& transport economics, skilled migration as well as housing \& welfare.

\section{Abstract:}

The invaluable social and economic contribution that women collectively make is often undervalued and underestimated. This paper attempts to redress this to some extent, by providing a contemporary assessment of women's contribution to on farm work in rural and regional communities in Australia. As part of the analysis, women's contributions to on farm activities and both their paid and unpaid work on farms was examined. Measures of the contribution of women in terms of their paid and unpaid on farm work were calculated using values derived from specially constructed models. A thorough review of relevant research concerning the determinants of women's contribution to the agricultural sector is also incorporated. The findings presented are thus largely based on current research, with one of the main goals of the exercise being to provide more complete information regarding the contribution of women to agricultural and regional communities, to better assist future policy development.

Keywords: gender, household production, unpaid work, agricultural work 


\section{Introduction}

A brief introduction to some of the issues to be addressed in arriving at estimates of women's contributions to agriculture serves to highlight some of the key areas covered and omitted in this paper. At a conceptual level there are a variety of ways in which the value of the work undertaken by a person or particular group of people might be estimated. For example, we might want to value work using one of the following approaches:

- The additional costs that would be incurred by an individual and/or others in the community if the work was not undertaken;

- The additional value added to the goods and services produced in the economy;

- The willingness of people to pay for the work being undertaken;

- The wages actually paid to the person undertaking the work.

In practice however, the monetary value of work is commonly equated with the wages or income paid to the person who undertakes the work. This is consistent with the national accounting convention that the exchange of goods or services in a market, including a labour market, is a defining feature of "economic activity". While this is a relatively straightforward approach, it presents particular challenges in the context of the current study. Firstly, women's on farm work is often not recorded as employment. While the labour devoted to farm work will affect the returns to a farm as an organisational unit, this does not typically take place in a form that records " $y$ dollars paid" for "women's $x$ hours of employment".

Secondly, valuing only labour market and farm activities means that unpaid volunteer, household and community activities are neglected. While this is consistent with the "production boundary" defined in national accounting conventions, it is clear that many economic activities implicitly assume and are dependent upon the unpaid activities that take place within communities and households. There are interdependencies between unpaid and paid activities in the economy that are not fully captured by conventional national accounts.

Thirdly, attributing a dollar value to women's and men's contributions to agricultural, household and community activities risks diverting attention away from a wide range of activities that elude such valuations. In this respect, special reference should be made to the importance of activities that often "hold the rural community together" and contribute to improving the "quality of life" in rural communities. These roles have again been emphasised in the broader context of this paper. Developing an estimate of the monetary value of any individual's or group's contribution to a community is unable to capture the full extent of the contributions being made.

The models that used in this paper were developed with full recognition of the above issues and the strengths and limitations of estimating women's economic and social contribution to agriculture as an industry and as a key component of rural and regional social and economic life. We similarly recognise both the 
advantages and disadvantages of constructing monetary assessments of activities that have significant social, as well as economic implications. This is one reason that the following assessments should be treated with some caution and considered alongside other research outcomes such as relevant qualitative analysis.

Within the limitations outlined above, the modelling in this paper is comprised of two stages. The first stage estimates the current contribution of women who live on farms in terms of paid and unpaid on-farm work in primary production. The second part involved estimating the paid on-farm work in primary or other production of men and women. Both these are contained in section three of the paper. Preceding this however is a discussion of the determinants of women's labour supply and patterns of work. This comprises the subject matter of the next section of the paper.

\section{Women's labour supply}

\subsection{Household, volunteer and community contributions}

Household production and unpaid volunteer and community work is not recorded as employment. Household production refers to unpaid activities undertaken within households which could potentially be undertaken by a market provider. For example, child care can be provided by unpaid labour within the household or by a paid child care provider. The defining features of household production are discussed in ABS (1998) and are generally traced to Reid's groundbreaking work on this subject (Reid 1934). Time use surveys provide estimates of the amount of time household members spend engaged in a range of activities, including those commonly referred to as "household production". The most recent time use survey estimates show that women undertake approximately two-thirds of the unpaid work that occurs within Australian households (ABS 2008a). Within this context, unpaid household work on farms is portrayed and generally perceived as women's work (Kelly and Shortall 2002; Liepins 1998; Whittenbury 2002).

Volunteer and community activities are another important area of unpaid contributions across Australian, including agricultural regions. The average volunteer rate is 32 per cent in Australian capital cities compared with 38 per cent outside of the capital cities. It is also higher among women with female representation among volunteers being 36 per cent, compared to 32 per cent for men (ABS 2007a). In total, the time use data gives a clear picture that monetary estimates of on farm work have significant limitations in terms of their capacity to adequately account for the full range of activities undertaken by women in agricultural communities. The data complements literature that demonstrates that Australian rural women's contributions to agriculture and rural communities is often unpaid, undervalued and largely invisible (Alston 2003; Liepins 1998; Pini 2004; Pini and Shortall 2006; Williams 2002). 


\subsection{Women's patterns of labour supply - on farm work}

Women's on farm contributions can be divided into the following types of activities:

- Paid on-farm work in primary or other production (such as secondary processing of farm product)

- Unpaid on-farm work in primary or other production (such as secondary processing of farm product)

Women's contributions to each of these activities depend on a range of factors. The following discussion summarises the findings from recent research. The goal of this section of the paper is to identify any relevant literature that would affect the underlying assumptions used for constructing assessments of women's contributions in section three. The reviewed literature has therefore been selected based on its relevance to key determinants of women's engagement in the above activities.

Although the literature on the significance of farm women's economic and social contributions has grown considerably in recent decades, significant gaps still remain in our understandings of the determinants of farm women's work, particularly with regard to their contributions to unpaid and paid work on farms and in farm households. The available literature does, however, confirm the previously identified links between women's patterns of paid and unpaid work across a range of on-farm activities.

\subsection{Determinants of on-farm work (paid and unpaid) in primary production}

A 1998 report undertaken for Australia's Rural Industries Research and Development Corporation reported that literature examining the on-farm work participation of farm women was very limited with only a small number studies having been completed (Centre for International Economics 1998). The few studies of relevance that had been done in the area were largely based on U.S research and involved the examination of the correlation between the socioeconomic characteristics of women in agriculture and their contribution to on farm work. Very little Australian research was identified, with the significant exception of Gooday (1995). Available findings suggested that women work relatively more on-farm FTE weeks if: the farm is under 200 hectares; has relatively low capitalisation; is in the dairy sector. Findings relevant to patterns of on-farm work among women with children were inconclusive for the American studies and comparable findings for Australian farms were unavailable.

Pini (2004) has outlined the extensive challenges of obtaining accurate, representative survey data that allows for quantitative analysis of women's patterns of on-farm work. The challenges result from a range of issues closely related to both finding representative samples of respondents and farm women's own perceptions of what might legitimately count as farm work. Pini notes that 
respondents sometimes reply that they don't undertake the role of a farmer but only participate in tasks such as farm administration, collecting necessary equipment or machinery parts, dealing with suppliers or undertaking catering duties to feed farm labourers. Despite an emerging formal recognition of farm women's roles as providers of on-farm labour, there appears to a continuing perception of farming as a role undertaken by men and a degree of reluctance among some farm women to overtly recognise their own roles as farmers.

Qualitative data provides a range of insights into some of the factors that influence women's participation in on-farm activities. As noted above, women appear to undertake a range of duties necessary to the administration and maintenance of farms as business enterprises. In addition, women supply additional farm labour during peak periods of operational activities such as in planting season (Pini 2004).

The relative lack of reliable survey research findings means that Australian Bureau of Agricultural and Resource Economics (ABARE) farm survey data plays a significant role in our understandings of women's contributions to agricultural production. As discussed in the following section, this data provides insights into the proportion of women who are farm operators and spouses and the hours they spend in on farm work.

\section{Estimating Women's Contributions}

\subsection{Background}

This section of the paper focuses on providing assessments of women's contributions to both agriculture and agricultural households and communities. It takes into account women's diverse roles in paid employment on farms and unpaid activities relevant to agricultural production.

Constructing monetary values relevant to women's various roles is not an objective exercise. It involves decisions about which activities to include, how to quantify the "volume" of those activities and the choice of an appropriate dollar value. The subjectivity involved in constructing monetary values for economic and social activity has long been recognised. For example, with reference to the construction of national accounts, particularly which activities do or don't count as "economic" activities Kuznets noted:

The statistician who supposes that he can make a purely objective estimate of national income, not influenced by preconceptions concerning the 'facts' is deluding himself; for whenever he includes one item or excludes another he is implicitly accepting some standard of judgement, his own or that of the compiler of his data. There is no escaping this subjective element in his work, or freeing the results from its effects. In consequence, all national income estimates are appraisals of the end 
products of the economic system rather than colourless statements of fact; and, like all appraisals, they are predetermined by criteria that are at worst a matter of chance, at best a matter of deliberate choice. (Kuznets 1941:3)

National accounts and a range of other official statistics are generally based on the assumption that "economic" activities are those that involve a market transaction such as paying for a commodity or exchanging labour for a fee or wage. This approach excludes many significant activities undertaken by those who perform unpaid work, most of which is undertaken by women. The approach taken in the following discussion is similar to that taken in a range of studies that recognise the importance of women's unpaid work for the effective functioning of both market and non-market activities. It is based on the view that a wide range of women's paid and unpaid activities represent important contributions to agricultural output, households and communities. Taking into account women's market and non market activities, the following discussions consider women's contributions to:

- Paid employment in agriculture;

- Unpaid work on farms;

- Paid on-farm work in primary or other production industries

Typically, economic assessments of these roles involve an assessment of the time input from those undertaking the relevant work and the application of some particular monetary value to that time. While this approach can give a broader appreciation of women's contributions to agriculture, some important issues remain neglected. The hours of time spent in an activity will not necessarily reflect qualitative aspects of a person's work such as their productivity, skill, creativity or innovation. The following discussion assumes that one person's input is identical with another's and in many cases, that the contribution of women's hours of work and employment are the same as men's. If women's work is qualitatively different because, as a group, they have relatively higher skill levels in areas such as communicating or informally exchanging information relevant to agricultural activity, then this will not be reflected in the following assessments. These are major limitations of the assessments that can only be addressed through different forms of data analysis along with a closer appreciation of the social workings of agricultural enterprises and communities.

\subsection{Some demographic and employment information relating to the Australian agricultural sector}

There have been significant changes in the number of people involved in farming and/or employed in the agricultural sector over the last two decades. It is important to understand some of these changes to provide a context for the construction of monetary assessments of women's contribution to agriculture in Australia. 
Women's contributions to agriculture in 2005/06 took place within a context of both a declining number of farms and farming families. As shown in Table 1 and Table 2, estimates from the Australian Bureau of Statistics (ABS) and the Australian Bureau of Agricultural and Resource Economics (ABARE) suggest a reduction of approximately 12 per cent in the number of farming families and 17 per cent in the number of farms compared with the 1996. Similarly, Table 3 shows a reduction in the number of agricultural establishments with a value of operations in excess of $\$ 5,000$ and Table 4 demonstrates declining numbers of people employed in agricultural industries. As illustrated in Table 5, depending on which of the above indicators are used, the agricultural sector might be considered to have contracted by between 11 and 17 per cent between 1996 and 2006.

Table 1: Number of farming families - Australia 1986-2006

Year

1986

Farming families

1991

1996

145,000

2001

120,400

115,100

112,800

2006 101,700

Source: 1986-2001: (Australian Bureau of Statistics 2004); 2006: (Australian Bureau of Statistics 2008b).

Table 2: Estimated population of farms in ABARE Farm Surveys 1990-2006

$\begin{array}{cccc}\text { Year } & \text { Broadacre Farms } & \text { Dairy } & \text { Total } \\ 1990 & 83,618 & 14,453 & 98,071 \\ 1991 & 82,066 & 13,851 & 95,917 \\ 1992 & 78,127 & 13,592 & 91,719 \\ 1993 & 76,884 & 13,607 & 90,491 \\ 1994 & 72,863 & 14,059 & 86,922 \\ 1995 & 71,026 & 13,854 & 84,880 \\ 1996 & 71,944 & 13,674 & 85,618 \\ 1997 & 70,828 & 13,433 & 84,261 \\ 1998 & 69,850 & 13,246 & 83,096 \\ 1999 & 67,874 & 12,781 & 80,655 \\ 2000 & 71,468 & 12,960 & 84,428 \\ 2001 & 70,213 & 12,602 & 82,815 \\ 2002 & 67,875 & 10,995 & 78,870 \\ 2003 & 72,256 & 11,266 & 83,522 \\ 2004 & 71,549 & 10,178 & 81,727 \\ 2005 & 70,551 & 10,112 & 80,663 \\ 2006 & 61,198 & 9,361 & 70,559\end{array}$

Source: (ABARE 2007c) http://www.abareconomics.com/ame/agsurf/agsurf.asp, accessed 15/02/2008 
Table 3: Number of agricultural establishments with EVAO* in excess of $\$ 5,000$ 1996- 2006

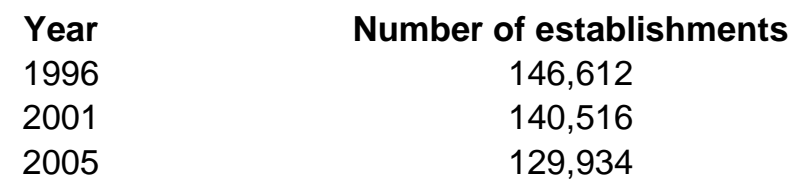

*Estimated Value of Agricultural Operations

Source: (Australian Bureau of Statistics 2006a; 2007b)

Table 4: Total Employment in Industry Code ANZSIC 01: Agriculture, Forestry and Fishing 1994-2006

$\begin{array}{cccc}\text { Year } & \text { Males ('000) } & \text { Females ('000) } & \text { Total ('000) } \\ 1994 & 284.5 & 120.9 & 405.4 \\ 1995 & 270.0 & 127.9 & 397.9 \\ 1996 & 286.2 & 124.5 & 410.7 \\ 1997 & 288.0 & 126.9 & 414.9 \\ 1998 & 269.9 & 126.1 & 396 \\ 1999 & 284.7 & 130.4 & 415.1 \\ 2000 & 294.6 & 131.8 & 426.4 \\ 2001 & 297.8 & 138.1 & 435.9 \\ 2002 & 270.2 & 115.4 & 385.6 \\ 2003 & 255.8 & 111.1 & 366.9 \\ 2004 & 235.4 & 110.4 & 345.8 \\ 2005 & 245.7 & 106.7 & 352.4 \\ 2006 & 247.8 & 105.4 & 353.2\end{array}$

Source: (Australian Bureau of Statistics 2007c)

Table 5: Changes in estimates relevant to selected agricultural activity 1996-2006

\begin{tabular}{|c|c|c|c|}
\hline & $\begin{array}{c}\text { Earlier } \\
\text { estimate } \\
(1996)\end{array}$ & $\begin{array}{c}\text { Recent } \\
\text { estimate(2006) }\end{array}$ & Change \\
\hline Number of Farming families: 1996 and 2006 & 115,100 & 101,700 & $-12 \%$ \\
\hline $\begin{array}{l}\text { Estimated Population of Number of Broadacre } \\
\text { and Dairy Farms: } 1996 \text { and } 2006\end{array}$ & 85,618 & 70,559 & $-17 \%$ \\
\hline $\begin{array}{l}\text { Number of Farms with EVAO in excess of } \\
\$ 5,000: 1996 \text { and } 2005\end{array}$ & 146,612 & 129,934 & $-11 \%$ \\
\hline Total Employment in Agriculture, Forestry and & 410,700 & 353,200 & $-14 \%$ \\
\hline
\end{tabular}

Fishing: 1996 and 2006

Source: Compiled from Tables 1-4, above.

The declining trends demonstrated in the demographic and employment indicators, combined with the availability of different data sources have important 
implications for the estimated number of farm women that forms the basis of several assessments made in this paper. In an attempt to update estimates about the number of women involved in farming activities, we have drawn on more recent data and made a number of assumptions about agricultural populations. Where possible the resulting estimates have been crossed checked with alternative data sources. Our estimates and data sources are summarised in Table 6 below.

\section{Table 6: Estimating the number of women per farm household 2006}

$\begin{array}{ll}\text { Variable } & \text { Estimate } \\ \text { Number of farms } & 101,000\end{array}$

Persons per farm household

Households per farm

Number of farm households
Persons in farm households

Number of women in farm households

Number of men in farm households
Data and assumptions for estimate

ABARE survey 2005/06 includes population estimates of 61,198 broadacre farms and 9,361 dairy farms. ABARE estimate that their survey represents about 70 per cent of farm business units. This implies that there are approximately 101,000 farms in Australia.

2006 Census data indicates that there were 101,753 farming families. This estimate includes only those families where either the reference person and/or their spouse reported their main occupation as farmer or farm manager. This number is therefore likely to more closely reflect the number of farms, rather than the total number of families involved in farming, many of whom will have occupations other than farmer or farm manager.

Estimate for non-metropolitan areas, Table 18, Australian Farm Sector Demography (2005:34).

Estimate for broadacre and dairy farm businesses from Garnaut and Lim-Applegate (1998) cited in Australian Farm Sector Demography (2005, page 21).

Estimated number of farms multiplied by estimated number of households per farm.

This estimate is broadly similar to ABS Census data which indicates that there are 166,511 families where the reference person or spouse works, is classified as working in the Australian and New Zealand Standard Industrial Classification (ANZSIC) code 01; Agriculture, Forestry and Fishing. While the Census based estimate is about 5,000 households fewer than the derived estimate of 171,000 , census data tends to show fewer people employed in agricultural classifications than labour force surveys and does not include farm workers who do not consider themselves "employed" (such as some partners who assist with farm activities).

429,250 Estimated number of farm households $(171,000)$ multiplied by estimated persons per farm household (2.5).

Based on gender ratio (M for 100F) for non metropolitan areas of 99.5 Table 18, Australian Farm Sector Demography (2005, page 34). areas of 99.5 Table 18, Australian Farm Sector 
Estimated number of women per farm
2.14

Based on rounded estimate of number of women in farm households $(251,700)$ divided by number of farms (101,000).

An estimate of 2.14 women per farm is broadly consistent with information that indicates a decline in the number of farm businesses, farm families and employees in agricultural classifications.

We have used the much lower estimate of the number of 215,700 farm women and 213,550 farm men which has significant implications. The first implication is that if there has been a significant reduction in the number of farm women but their output within agriculture, households and local communities is either constant or growing, then it signals that there are significant improvements in individual productivity. This however will not be captured in the following assessments. The second, and equally important, implication is that estimates of women's aggregate hours of unpaid work will be relatively low reflecting a disproportionately large estimated drop in the population of farm women. This has significant implications for both the estimated volume and value of unpaid work.

\subsection{Paid and unpaid on-farm work in primary production}

Paid and unpaid on-farm production is estimated using a "top down" approach. This means that GDP attributable to the Agricultural sector is apportioned between women and men according to their input of hours into agricultural production.

As noted in section two of the paper, women's farm activities differ according to a range of variables, including farm size, remoteness, household composition, age and education. Some of these differences can be accounted for by disaggregating agricultural output by sector. This has been done for two reasons. Firstly, as already stated, patterns of work and employment differ by sector. Secondly, the Australian Bureau of Agricultural and Resource Economics (ABARE) undertake extensive surveys of broadacre and dairy farming establishments and produce findings disaggregated by sector. Adopting a similar format facilitates use of this important and unique source of data. The contribution of a range of sectors to the agricultural component of GDP is shown in Table 7. Total contribution to GDP is estimated at almost $\$ 26$ billion. 
Table 7: Agricultural contribution to GDP by sector 2005/06

\begin{tabular}{|l|r|r|}
\hline & \multicolumn{2}{|c|}{ Contribution to GDP } \\
\hline Sector & $\begin{array}{c}\text { \% (a) to agricultural } \\
\text { production }\end{array}$ & $\$ \mathrm{~m}$ '000 \\
\hline Wheat and other crops & 21.3 & 5,485 \\
\hline Mixed livestock -crop & 9.4 & 2,432 \\
\hline Sheep & 7.5 & 1,935 \\
\hline Beef & 13.8 & 3,552 \\
\hline Sheep-beef & 5.0 & 1,291 \\
\hline Dairy & 8.7 & 2,237 \\
\hline Cotton & 2.9 & 740 \\
\hline Sugarcane & 3.5 & 891 \\
\hline Fruit & 6.9 & 1,775 \\
\hline Other livestock (b) & 7.0 & 1,809 \\
\hline Other crops (c) & 14.0 & 3,617 \\
\hline Total Agricultural Contribution & 100.0 & 25,764 \\
\hline
\end{tabular}

Note: This table uses the following assumptions:

-20 per cent of wheat and other crops grown on mixed livestock and/or crop.

-20 per cent of sheep and 10 per cent of beef grown on mixed livestock

-10 per cent of sheep and 20 per cent of beef on sheep-beef.

- Shares are based on gross value of production over 2005/06.

(a) Shares based on gross value of production stated in (b) calculation by subtracting classified livestock categories from total livestock figures (c) calculated by subtracting classified crops from total crop production as figures in ABARE 2007 Table 21 do not total 20724

Sources: (ABARE 2007a: Table 21; Australian Bureau of Statistics 2006c: Table 9)

Detailed information about selected characteristics of broadacre and dairy farms is provided in Table 8 and Table 9 and this provides some insights into key differences between different agricultural sectors. For example, average farm size varies significantly and is relatively much larger for the beef sector, with likely implications for accessibility to off-farm employment. Average annual labour inputs also vary markedly with wheat farms requiring an average of 29 weeks more labour than sheep farms. These estimates reinforce the argument for using disaggregated data where available and provide inputs for later assessments of women's contribution to agriculture.

As discussed above, the estimated total number of farms in Australia in 2006 is 101,000. Unpublished data from ABARE indicate that a number of farms have female "operators" or managers, constituting about five per cent of operators in the broadacre and dairy farms. This data demonstrates that while many women perform the role nominated as "spouse" in farming surveys, there is a significant minority who are formally undertaking the role of farm manager or operator. This has implications for estimating the average hours worked on and off farms by farm women. Previously it has been assumed that all farm women performed the number of hours collected for those in the spouse role. This new data allows us to consider the different contributions made by farm women in different roles, summarised in Table 9, and to weight the average number of hours to account for the working time spent by women in an operator or manager role. ABARE data on working hours by sons and daughters living in farm households, also included in Table 9, provides further insights into the allocation of farm work. 
Table 8 also summarises some of the categories of data that are unavailable for farming establishments that are not covered by ABARE surveys. Throughout this study, "other" sectors are assumed to have characteristics similar to the "average" farm covered by ABARE farm surveys, as shown in Table 9. This assumption is particularly important with respect to estimates of women's participation in unpaid agricultural activities.

Table 8: Characteristics of broadacre and dairy farms

\begin{tabular}{|c|c|c|c|c|c|c|c|c|}
\hline & Estimated & Jumber of $F$ & rms (a) & $\begin{array}{l}\text { Average } \\
\text { labour } \\
\text { used (c) }\end{array}$ & $\begin{array}{l}\text { Average } \\
\text { farm } \\
\text { size (c) }\end{array}$ & $\begin{array}{l}\text { Average } \\
\text { farm } \\
\text { cash } \\
\text { income } \\
\text { (b) }\end{array}$ & $\begin{array}{l}\text { Off-farm } \\
\text { income } \\
\text { (b) }\end{array}$ & $\begin{array}{l}\text { On- } \\
\text { farm/off- } \\
\text { farm } \\
\text { cash } \\
\text { income } \\
\text { (b) }\end{array}$ \\
\hline & $\begin{array}{c}\text { With } \\
\text { female } \\
\text { operators }\end{array}$ & $\begin{array}{c}\text { With } \\
\text { male } \\
\text { operators }\end{array}$ & $\begin{array}{c}\text { Total } \\
\text { incl } \\
\text { corp } \\
\text { farms }\end{array}$ & $\begin{array}{l}\text { FTE } \\
\text { week } \\
\text { s/year }\end{array}$ & ha & $\begin{array}{c}\$ \\
2005 / 06\end{array}$ & $\begin{array}{c}\$ \\
2005 / 06\end{array}$ & ratio \\
\hline $\begin{array}{l}\text { Wheat and } \\
\text { other crops }\end{array}$ & 214 & 10,475 & 10,715 & 122 & 2,372 & $\begin{array}{r}14,056 \\
3 \\
\end{array}$ & 28,030 & 5.0 \\
\hline $\begin{array}{l}\text { Mixed } \\
\text { livestock/crop }\end{array}$ & 423 & 13,677 & 14,137 & 102 & 2,276 & 74,490 & 32,555 & 2.3 \\
\hline Sheep & 722 & 11,317 & 12,067 & 93 & 6,562 & 82,100 & 29,963 & 2.7 \\
\hline Beef & 1,389 & 15,968 & 17,660 & 107 & 15,067 & 39,390 & 34,384 & 1.1 \\
\hline Sheep/Beef & 784 & 5,752 & 6,619 & 103 & 6,651 & 63,240 & 27,936 & 2.3 \\
\hline Dairy & 556 & 8,717 & 9,361 & 136 & 247 & 86,030 & 19,345 & 4.4 \\
\hline Other & 1,522 & 28,919 & 30,441 & NA & NA & NA & NA & NA \\
\hline $\begin{array}{l}\text { Total } \\
\text { Australia }\end{array}$ & 5,610 & 94,825 & $\begin{array}{r}101,00 \\
0\end{array}$ & NA & NA & NA & NA & NA \\
\hline
\end{tabular}

Notes; (a) "Other" has been estimated as a residual of estimated total number of farms. Gender division for "other" is based on a 5\% allocation to female operators, the average for broadacre and dairy farms.

Sources: (b) (ABARE 2007b); (c) (ABARE 2007c)

Table 9: Full time equivalent weeks worked on-farm per year, average per farm 2005/06

\begin{tabular}{|l|c|c|c|c|c|c|c|}
\hline & $\begin{array}{l}\text { Female } \\
\text { operator }\end{array}$ & $\begin{array}{l}\text { Male } \\
\text { operator }\end{array}$ & $\begin{array}{l}\text { Female } \\
\text { spouse }\end{array}$ & $\begin{array}{l}\text { Male } \\
\text { spouse }\end{array}$ & Daughter & Son & $\begin{array}{l}\text { Total } \\
\text { Farm } \\
\text { Labour* }\end{array}$ \\
\hline Wheat and other crop & 47 & 48 & 24 & 40 & 4 & 18 & 122 \\
\hline Mixed livestock & 41 & 48 & 22 & 18 & 5 & 21 & 102 \\
\hline Sheep & 32 & 48 & 26 & 42 & 4 & 14 & 93 \\
\hline Beef & 45 & 47 & 28 & 40 & 7 & 15 & 107 \\
\hline Sheep-Beef & 47 & 48 & 29 & 17 & 5 & 15 & 103 \\
\hline Dairy & 50 & 50 & 34 & 50 & 14 & 21 & 136 \\
\hline All Industries & 42 & 48 & 26 & 32 & 5 & 17 & 105 \\
\hline
\end{tabular}

*includes labour from outside farm families/households

Source: Unpublished data from ABARE, Farm Surveys, 2005/06. 
The data outlined in the previous tables allows us to construct estimates relevant to women's contributions to GDP through their paid and unpaid on-farm work, summarised in Table 10. Available data stipulates that the proportions of on-farm paid and unpaid hours worked by all farm women are assumed to be equivalent to the proportion of hours worked by women operators and spouses. Table 10 shows that women are estimated to contribute one third of total hours worked on farms. Assuming that the contribution of hours worked reflects women's proportional contribution to GDP, they can be inferred to reflect a contribution of one third of farm GDP; approximately $\$ 8.6$ billion in 2005/06.

Table 10: Women's on-farm contribution as a share of GDP at market prices 2005/06 (a)

\begin{tabular}{|c|c|c|c|c|c|c|c|c|}
\hline & \multicolumn{2}{|c|}{ Operators } & \multicolumn{2}{|c|}{ Spouses } & \multirow{2}{*}{$\begin{array}{l}\text { Weighted } \\
\text { FTE all farm } \\
\text { women }\end{array}$} & \multirow{2}{*}{$\begin{array}{l}\text { Proporti } \\
\text { on of } \\
\text { hours } \\
\text { worked } \\
\text { by } \\
\text { women - } \\
\text { main } \\
\text { couple }\end{array}$} & \multirow{2}{*}{$\begin{array}{l}\text { Sector } \\
\text { GDP } \\
\text { contributi } \\
\text { on }\end{array}$} & \multirow{2}{*}{$\begin{array}{l}\text { Women's } \\
\text { contributi } \\
\text { on }\end{array}$} \\
\hline & \multirow{2}{*}{$\begin{array}{l}\text { Part }{ }^{n} \\
\text { rate } \%\end{array}$} & \multirow{2}{*}{$\begin{array}{c}\text { Avg. } \\
\text { FTE } \\
\text { weeks } \\
\text { pa }\end{array}$} & \multirow{2}{*}{$\begin{array}{l}\text { Part }{ }^{\mathrm{n}} \\
\text { rate } \%\end{array}$} & \multirow{2}{*}{$\begin{array}{c}\text { Avg. } \\
\text { FTE } \\
\text { weeks } \\
\text { pa }\end{array}$} & & & & \\
\hline & & & & & Weeks pa & Ratio & $\begin{array}{c}\$ m \\
2005 / 06\end{array}$ & $\begin{array}{c}\$ \mathrm{~m} \\
2005 / 06\end{array}$ \\
\hline $\begin{array}{l}\text { Wheat and } \\
\text { other crop }\end{array}$ & 2 & 47 & 89 & 24 & 22.3 & 0.32 & 5,485 & 1,754 \\
\hline $\begin{array}{l}\text { Mixed } \\
\text { livestock }\end{array}$ & 3 & 41 & 85 & 22 & 19.9 & 0.30 & 2,432 & 725 \\
\hline Sheep & 6 & 32 & 73 & 26 & 20.9 & 0.31 & 1,935 & 609 \\
\hline Beef & 8 & 45 & 78 & 28 & 25.4 & 0.36 & 3,552 & 1271 \\
\hline Sheep-Beef & 12 & 47 & 79 & 29 & 28.6 & 0.40 & 1,291 & 513 \\
\hline Dairy & 6 & 50 & 47 & 34 & 19.0 & 0.29 & 2,237 & 639 \\
\hline $\begin{array}{l}\text { Other } \\
\text { agriculture }\end{array}$ & 5 & 42 & 81 & 26 & 23.2 & 0.33 & 8,832 & 2,934 \\
\hline All Industries & 5 & 42 & 81 & 26 & 23.2 & 0.33 & 25,764 & 8,558 \\
\hline
\end{tabular}

Note: (a) Based on on-farm work by gender and industry - main couple only

Sources: Unpublished data from ABARE, Farm Surveys, 2005/06; (Australian Bureau of Statistics 2006c).

\subsection{Paid on-farm work in primary or other production}

The importance of considering women's unpaid work in primary production can be demonstrated by constructing alternative estimates based on official employment and earnings data. By omitting women's unpaid contributions and applying monetary valuations that reflect women's relatively lower rates of pay in the formal labour market, these estimates reflect a reduced assessment of women's contribution to on-farm activities in agriculture. 
Table 11 summarises employment data for women working in the Australian and New Zealand Standard Industrial Classification (ANZSIC) classification code 01; Agricultural, Forestry and Fishing. Using statistics based on survey respondents recognition of their role as a paid "employee" or "owner manager" gives a lower estimate than of both the number of women workers on farms and the proportion of farm labour provided by women compared with the estimates used above. For example, based on data for the "main couple", ABARE farm surveys suggest that over 80 per cent of women on farms participate in on-farm work. Given an estimated population of farm women of 215,700 this would indicate that over 172,000 women work on farms each year in either a full-time or part-time capacity. Labour force data suggests however, that there are 103,000 women working in the industry. There are likely to be a range of reasons for this substantial difference including: contrasting survey methods and definitions, women's own views and responses about their "employment" status; and statistician's recognition of women's on farm activities.

The differences in the two estimates of the number of women working on farms lead to significant differences in assessments of women's contribution to the agricultural sector. This is illustrated by the data included in Table 11, which shows official employment estimates indicating that women comprise slightly less than 30 per cent of the agricultural workforce and perform just under 22 per cent of paid hours of employment undertaken within the agricultural industry sector. If only 22 per cent of the sector's contribution to GDP were attributed to women then the resulting estimate would be approximately $\$ 3$ billion lower than the previous estimate shown in Table 10.

Table 11: Hours worked in Agricultural Industries* by gender, August 2006

\begin{tabular}{|c|c|c|c|c|}
\hline & & \multicolumn{2}{|c|}{ Weekly hours worked } & $\begin{array}{l}\text { Share of } \\
\text { Agricultural } \\
\text { Industry } \\
\text { employed } \\
\text { hours \% }\end{array}$ \\
\hline & & $\begin{array}{l}\text { Average per } \\
\text { person }\end{array}$ & $\begin{array}{c}\text { Total for group } \\
\text { '000 }\end{array}$ & \\
\hline \multicolumn{5}{|l|}{ Female '000 } \\
\hline Full time employees & 20.1 & 45.9 & 922.59 & 6.3 \\
\hline Full time owner managers & 34.4 & 45.9 & 1578.96 & 10.7 \\
\hline Part time employees & 12 & 14.6 & 175.2 & 1.2 \\
\hline Part time owner managers & 36.5 & 14.6 & 532.9 & 3.6 \\
\hline Total & 103.0 & & $3,209.65$ & 21.8 \\
\hline \multicolumn{5}{|l|}{ Male '000 } \\
\hline Full time employees & 90.9 & 51.1 & 4644.99 & 31.5 \\
\hline Full time owner managers & 126.9 & 51.1 & 6484.59 & 44.0 \\
\hline Part time employees & 11 & 14.9 & 163.9 & 1.1 \\
\hline Part time owner managers & 15.5 & 14.9 & 230.95 & 1.6 \\
\hline Total & 244.3 & & $11,524.43$ & 78.2 \\
\hline
\end{tabular}

* Employment in ANZSIC major category Agriculture, Forestry and Fishing

Source: (Australian Bureau of Statistics 2007c) 
Further contrasting demonstrations of the significance of women's contribution to agriculture show the effects of using a value added, top down approach (Table 10) compared with a "bottom up" approach based on surveys of working hours in formal employment and average earnings data. This approach uses estimates of women's on-farm hours of work and earnings to determine the aggregate earnings of agricultural women attributable to their on-farm, paid work. This approach assumes that women's earnings (and therefore the value of their onfarm employment) equals their marginal product.

Two different "bottom up" estimates have been constructed. In Table 12 women's estimated total paid and unpaid contributions to farm work (derived for Table 10) have been valued at a women's average weekly wage rate as at May 2006. An average for all industries has been used because average wage rates are unavailable for the agricultural sector. Using this approach, women's contribution is valued at $\$ 4.5$ billion. This is lower than both "top down" estimates derived above. Using the same approach for men gives a value of approximately $\$ 10.2$ billion, meaning that women's contribution is estimated at approximately 30 per cent of the total wage income value of paid on-farm work. While women's contribution of weeks worked remains the same as in the "top down" approach summarised in Table 10, their contribution relative to men has declined because of the application of a female wage rate, which is lower than the corresponding male wage rate. The different wage rates are not necessarily indicative of differences in the marginal productivity of men and women. Australia has a long and ongoing record of women's disproportionate representation in lower paying occupations (Preston 2001; Preston and Jefferson 2007). 
Table 12: Equivalent wage income of farm women and men - paid and unpaid on-farm work 2005/06

\begin{tabular}{|c|c|c|c|c|c|}
\hline & $\begin{array}{l}\text { Estimated } \\
\text { number of } \\
\text { Farms }\end{array}$ & $\begin{array}{l}\text { Estimated } \\
\text { population }\end{array}$ & $\begin{array}{l}\text { Average } \\
\text { FTE } \\
\text { weeks }\end{array}$ & $\begin{array}{l}\text { Average } \\
\text { weekly } \\
\text { wage* }^{*}\end{array}$ & $\begin{array}{l}\text { Wage } \\
\text { contribution } \\
\$ \mathrm{~m} \mathrm{2005/06}\end{array}$ \\
\hline \multicolumn{6}{|l|}{ Women } \\
\hline $\begin{array}{l}\text { Wheat and other } \\
\text { crops }\end{array}$ & 10,715 & 22,883 & 22.3 & 915.30 & 467.1 \\
\hline Mixed livestock & 14,137 & 30,191 & 19.93 & 915.30 & 550.7 \\
\hline Sheep & 12,067 & 25,770 & 20.9 & 915.30 & 493.0 \\
\hline Beef & 17,660 & 37,715 & 25.44 & 915.30 & 878.2 \\
\hline Sheep-Beef & 6,619 & 14,136 & 28.55 & 915.30 & 369.4 \\
\hline Dairy & 9,361 & 19,991 & 18.98 & 915.30 & 347.3 \\
\hline Other agriculture & 30,441 & 65,010 & 23.16 & 915.30 & $1,378.1$ \\
\hline All Industries & 101,000 & 215,700 & 23.16 & 915.30 & $4,483.8$ \\
\hline \multicolumn{6}{|l|}{ Men } \\
\hline $\begin{array}{l}\text { Wheat and other } \\
\text { crops }\end{array}$ & 10,715 & 22,652 & 47.4 & 1035.9 & $1,113.2$ \\
\hline $\begin{array}{l}\text { Wheat and other } \\
\text { crops }\end{array}$ & 10,715 & 22,652 & 47.4 & 1035.9 & $1,113.2$ \\
\hline Mixed livestock & 14,137 & 29,886 & 46.9 & 1035.9 & $1,452.6$ \\
\hline Sheep & 12,067 & 25,510 & 45.5 & 1035.9 & $1,203.4$ \\
\hline Beef & 17,660 & 37,333 & 45.6 & 1035.9 & $1,765.1$ \\
\hline Sheep-Beef & 6,619 & 13,993 & 43.3 & 1035.9 & 627.0 \\
\hline Dairy & 9,361 & 19,789 & 47.5 & 1035.9 & 973.7 \\
\hline Other agriculture & 30,441 & 64,352 & 46.6 & 1035.9 & $3,103.8$ \\
\hline All Industries & 10,1000 & 21,3514 & 46.6 & 1035.9 & $10,238.8$ \\
\hline
\end{tabular}

Note: Some column totals do not add due to rounding.

*Source: (Australian Bureau of Statistics 2007d: Average weekly ordinary time earnings for nonmanagerial full time female and male employees)

A second "bottom up" approach can be undertaken by using the same labour input shown in Table 11 (formal employment only) and applying average men's and women's wage rates to those estimates. This approach differs from that above by considering only those individuals who are included in official employment statistics and by applying gender specific wage rates to those undertaking management and other roles in agriculture. This approach increases the estimated value of men's contributions, reflecting not only their relatively higher number of working weeks but also their relatively higher recognition in employment statistics and higher rates of pay. Women's estimated contributions are relatively lower in Table 13 than in Table 12; they are less likely to have their roles recorded as official employment and their wages are relatively lower than men's.

Table 13: Equivalent wage income of employed farm women and men paid on-farm work 2005-06

\begin{tabular}{|l|l|l|l|l|}
\hline Women & No '000 & $\begin{array}{r}\text { FTE } \\
\text { Weeks }\end{array}$ & $\begin{array}{l}\text { Average } \\
\text { weekly }\end{array}$ & \$m 2006 \\
\hline
\end{tabular}




\begin{tabular}{|l|c|c|c|c|}
\hline & & & wage & \\
\hline Employees & 32.1 & 34.2 & 913.50 & 1,005 \\
\hline Owner managers & 70.9 & 29.8 & $1,178.70$ & 2,488 \\
\hline Total & & & & 3,493 \\
\hline Men & & & & \\
\hline Employees & 101.9 & 47.2 & $1,035.90$ & 4,981 \\
\hline Owner managers & 132.4 & 47.2 & $1,461.40$ & 9,125 \\
\hline Total & & & & 14,106 \\
\hline
\end{tabular}

*Source: (Australian Bureau of Statistics 2007d: Average weekly ordinary time earnings for female and male managerial employees (Table 8) and all non managerial female and male employees (Table 7).)

In summary, the contrasting methods of deriving a value to quantify women's onfarm work contribution demonstrates the importance of considering women's paid and unpaid inputs of time and the sensitivity of estimates to the application of men's and women's earnings data. The "top down" approach, includes estimates of both paid and unpaid hours and provides a closer approximation to a "value added" approach to the value of agricultural output. This is the estimate used later in this study to represent women's total contribution to on-farm agricultural work.

\section{Conclusion}

It has been widely noted that women in Australia make substantial contributions to both farm output and the social fabric of rural communities. This situation is not unique to Australia or agricultural work; it is widely recognised as a common feature of much of the work undertaken by women worldwide. Nor is this situation new. Margaret Reid (1934) recognised the economic and social significance of unpaid work and her definition of household work continues to be influential. Simon Kuznets, a Nobel Prize winner in economics, explicitly recognised the deficiencies of National Accounting Systems which did not include women's household work (1941, p.3).

Of course, the hidden or invisible nature of rural women's roles is relative. One need only look at the relative lack of information on the role of indigenous women for a more stark example of invisible work (Goreng 2002), and a recent ABARE publication as an example of emerging attempts to redress this neglect (Rodriguez, Puangsumalee and Griffiths 2006). The comparative invisibility of much of women's work however has implications for the industry and community issues that should be recognised and addressed by public policy. In both developed and less developed economies, the relative invisibility of women's contribution to agriculture means that the full social and economic implications of interactions between the agricultural sector and other sectors of the economy and the community can remain unrecognised. This can have significant implications for outcomes related to human capital formation and utilisation, income distribution and the economic and social wellbeing of those in agricultural communities. 
Increasing and maintaining the visibility of women's contributions is therefore critical to ensuring policy developments that take into account rural women's well being are implemented (Alston 2002; 2006; McKenzie 2002). The move towards improving rural women's visibility has occurred alongside increasing attention being paid to methods of ensuring the wider "hidden" economy becomes visible and explicitly drawing particular focus on the economic and social value of women's contributions to particular industries, occupations and social undertakings. These range from "gender impact assessments" of specific public policies to projects that value or provide monetary estimates of women's unpaid work (Himmelweit 2002). As this paper demonstrates, there is thus a need for such economic assessments to be understood within the broader context of women's lives and the distinctive, qualitative contributions they make to their households, businesses and local communities. The need for data that is specific both to paid and unpaid work contributions as well as specific geographic locations however means that the models used in this project cannot be seamlessly transferred to construct similar assessments for women working in other industries. In addition, there are strong reasons for tailoring such assessments to specific studies of industries or locations, rather than adopting a uniform approach.

\section{References}

ABARE. 2007a. Australian Commodities, 14:21.

ABARE. 2007b. Australian Farm Survey Results 2004-05 to 2006-97. Canberra: Australian Bureau of Agricultural and Resource Economics.

ABARE. 2007c. "Australian Farm Surveys, Agsurf data." Vol. 2008. ABARE.

Alston, Margaret. 2002. "Australian rural women: Mainstreaming the agenda." Setting the agenda for rural women: research directions, Conference proceedings and recommendations: 23-35. Centre for Rural Social Research: Charles Sturt University, Wagga Wagga.

Alston, Margaret. 2003. "Women in Agriculture: the 'New Entrepreneurs'." Australian Feminist Studies, 18:41, pp. 163-71.

Alston, Margaret. 2006. "Gender mainstreaming in practice: a view from rural Australia." NSWA Journal, 18:2, pp. 123-47.

Australian Bureau of Statistics. 1998. How Australians Use Their Time, Catalogue 4153.0. Canberra: Australian Bureau of Statistics.

Australian Bureau of Statistics. 2003. Western Australian Statistical Indicators, Catalogue 1367.5. Canberra: Australian Bureau of Statistics.

Australian Bureau of Statistics. 2004. "Australian Social Trends, Catalogue 4102.0." Australian Bureau of Statistics: Canberra.

Australian Bureau of Statistics. 2005. ANZSCO - Australian and New Zealand Standard Classification of Occupations, Catalogue 1221.0. Canberra: Australian Bureau of Statistics. 
Australian Bureau of Statistics. 2006a. Agricultural commodities 2004/05, Catalogue 7121.0. Canberra: Australian Bureau of Statistics.

Australian Bureau of Statistics. 2006b. Australian and New Zealand Standard Industrial Classification, ANZSIC, Catalogue 1292.0. Canberra: Australian Bureau of Statistics.

Australian Bureau of Statistics. 2006c. Australian System of National Accounts 2005/06 Catalogue 5204.0. Canberra: Australian Bureau of Statistics.

Australian Bureau of Statistics. 2007a. Voluntary work Australia catalogue 4441.0. Canberra: Australian Bureau of Statistics.

Australian Bureau of Statistics. 2007b. Australian farming in brief, catalogue 7106.0. Canberra: Australian Bureau of Statistics.

Australian Bureau of Statistics. 2007c. Australian labour market statistics catalogue 6105.0. Canberra: Australian Bureau of Statistics.

Australian Bureau of Statistics. 2007d. Employee Earnings and Hours May 2006, Catalogue 6306.0. Canberra: Australian Bureau of Statistics.

Australian Bureau of Statistics. 2008a. How Australians Use Their Time, 2006, Catalogue 4153.0. Canberra: Australian Bureau of Statistics.

Australian Bureau of Statistics. 2008b. Australian Census of Population and Housing 2006 Unpublished Data Request.

Australian Bureau of Statistics. 2008c. Western Australian Statistical Indicators, December Quarter 2007, Catalogue 1367.5. Canberra: Australian Bureau of Statistics.

Centre for International Economics. 1998. "Missed opportunities - harnessing the potential of women in Australian agriculture, volume 2." Rural Industries Research and Development Corporation and Department of Primary Industries and Energy: Canberra.

Garnaut, J and H Lim-Applegate. 1998. "People in farming: ABARE Research Report 98.6." Australian Bureau of Agriculture and Resource Economics: Canberra.

Gooday, Jane. 1995. Women on Farms: A survey of women on Australian broadacre and dairy farms, 1993/94 (ABARE Research Report 95.10). Canberra: ABARE.

Goreng, Tjanara Goreng. 2002. "Recovering our strength and cultural voice: Indigenous women in rural Australian communities engaging with rural Australia." Setting the agenda for rural women: research directions, Conference proceedings and recommendations: 64-67. Centre for Rural Social Research: Charles Sturt University, Wagga Wagga.

Himmelweit, Susan. 2002. "Making visible the hidden economy: The case for gender impact analysis of economic policy." Feminist Economics, 8:1, pp. 40-70.

Kelly, Roisin and Sally Shortall. 2002. "'Farmers' wives': women who are off-farm breadwinners and the implications for on-farm gender relations." Journal of Sociology, 38:4, pp. 327-43. 
Kuznets, Simon. 1941. National Income and its Composition 1919-1938. New York: National Bureau of Economic Research.

Liepins, Ruth. 1998. "The gendering of farming and agricultural politics: a matter of discourse and power." Australian Geographer, 29:3, pp. 371-88.

Lim-Applegate, Hazel, Gil Rodriguez, and Rose Olfert. 2002. "Determinants of non-farm labour participation rates among farmers in Australia." Australian Journal of Agricultural and Resource Economics, 46:1, pp. 85-98.

McKenzie, Fiona Haslam. 2002. "Strategies for getting the girls back on centre stage." Setting the agenda for rural women: research directions, Conference proceedings and recommendations: 36-46. Centre for Rural Social Research: Charles Sturt University, Wagga Wagga.

Pini, Barbara. 2004. "Counting them in, not out: Surveying farm women about agricultural leadership." Australian Geographical Studies, 42:2, pp. 24959.

Pini, Barbara and Sally Shortall. 2006. "Gender equality in agriculture: examining State intervention in Australia and Northern Ireland." Social Policy and Society, 5:2, pp. 199-206.

Preston, Alison. 2001. The Structure and Determinants of Wage Relativities: Evidence from Australia. Aldershot: Ashgate Publishing Limited.

Preston, Alison, and Therese Jefferson. 2007. "Trends in Australia's Gender Wage Ratio." Labour and Industry 18:2, pp. 69-84.

Reid, Margaret Gilpin. 1934. Economics of Household Production. New York: Wiley.

Rodriguez, Veronia, Phantipa Puangsumalee, and Greg Griffiths. 2006. "Indigenous people working in agriculture, fisheries and forestry." Australian Bureau of Agricultural and Resource Economics (ABARE): Canberra.

Synapse Research and Consulting Pty Ltd and Bob Hudson Consulting Pty Ltd. 2005. "Australian Farm Sector Demography: Analysis of current trends and future farm policy implications." Australian Farm Institute: Sydney.

Whittenbury, Kerri. 2002. "Obscuring potential alternatives: how traditional ideology influences expectations of and for women in a rural community." Setting the agenda for rural women: research directions, Conference proceedings and recommendations: 150-60. Centre for Rural Social Research: Charles Sturt University, Wagga Wagga.

Williams, Rachael. 2002. "Recognising and valuing women in developing policy for community capacity building: a focus on the interplay between leadership and social capital." Setting the agenda for rural women: research directions, Conference proceedings and recommendations: 16176. Centre for Rural Social Research: Charles Sturt University, Wagga Wagga. 